\title{
Seismic resistance and endurance of the typical residential buildings in Sochi
}

\author{
Elena Yurchenko ${ }^{1}$, Alexander Volkov $^{1,{ }^{*}}$ and Asthik Kakosyan ${ }^{1}$ \\ ${ }^{1}$ Sochi State University, Ecology and Engineering Faculty, Sovetskaya street, 26A, 354000, Sochi, \\ Russia
}

\begin{abstract}
The typical residential buildings of the 1960-90s are a significant part of Sochi's housing stock, similar to other cities in Russia. Nowadays they are in the half of their design life. The purpose of the study is to determine the reliability and endurance of operation under conditions of seismic intensity degree VIII by the MSK-64 scale (Medvedev-SponheuerKarnik scale), the humid subtropical climate, Sochi's housing density, and the rugged terrain. Studies of the technical condition of buildings and facilities have been conducted in Sochi State University for 20 years. According to the building codes, the categories of the technical state of both structural elements and building construction were defined, reliability values were calculated, and types of defects were identified. Methods of conducting current repairs and local seismic retrofitting to achieve the characteristic value of buildings' endurance were proposed.
\end{abstract}

\section{Introduction}

Within the framework of a comprehensive target program aimed to ensuring seismic protection of socially significant and residential buildings and focused on realizing the goals of the federal target program "Improving the sustainability of residential buildings and the main objects of life-support systems in seismic regions of the Russian Federation for 20092018" [1], due to the preparation for the World Cup 2018, the authors conducted a comprehensive studies of representative houses of a typical residential building in the city of Sochi.

This work is an continuation of the research and is carried out by the authors since 1999, when its results were presented on the 3rd Russian Conference on Earthquake-Resistant Construction and Seismic Zoning for the first time, and later in 2006 in materials [1] on the scale of the Federal Target program "Seismic safety of the territory of Russia 2002-2010". Nowadays, typical buildings made of prefabricated reinforced concrete or lightweight concrete structures on the territory of Russia, as a rule, are in the half of the design life. Typical buildings in the coastal part of Sochi, erected in the 1960s and 1990s are no exception.

The studies were carried out for twenty residential houses-representatives of the

\footnotetext{
*Corresponding author: volkovsochi@gmail.com
} 
following standard series in quantities proportional to the representation in the building (fig. 1):

a) the construction of the $1960 \mathrm{~s}$

- five-storey frame-panel for the series 1-335 without anti-seismic measures - 1 house;

- four-storey with external and internal longitudinal bearing brick walls without antiseismic measures - 2 houses;

- three-storey large-block with external and internal longitudinal bearing concrete walls without anti-seismic measures - 2 houses;

b) the construction of the $1970 \mathrm{~s}$

- five-storey frame-panel for the 1-335 series with anti-seismic measures for the intensity degree VII by the MSK-64 scale - 9 houses;

- five-storey volumetric-block with anti-seismic measures for the intensity degree VII - 2 houses;

c) building of the $1980-90 \mathrm{~s}$

- twelve-storey in the series 1-467 with large panels with anti-seismic measures for the intensity degree VIII by the MSK-64 scale - 1 house;

- nine-storey in the series 1-135 with large panels with anti-seismic activities for the intensity degree VIII - 3 houses.

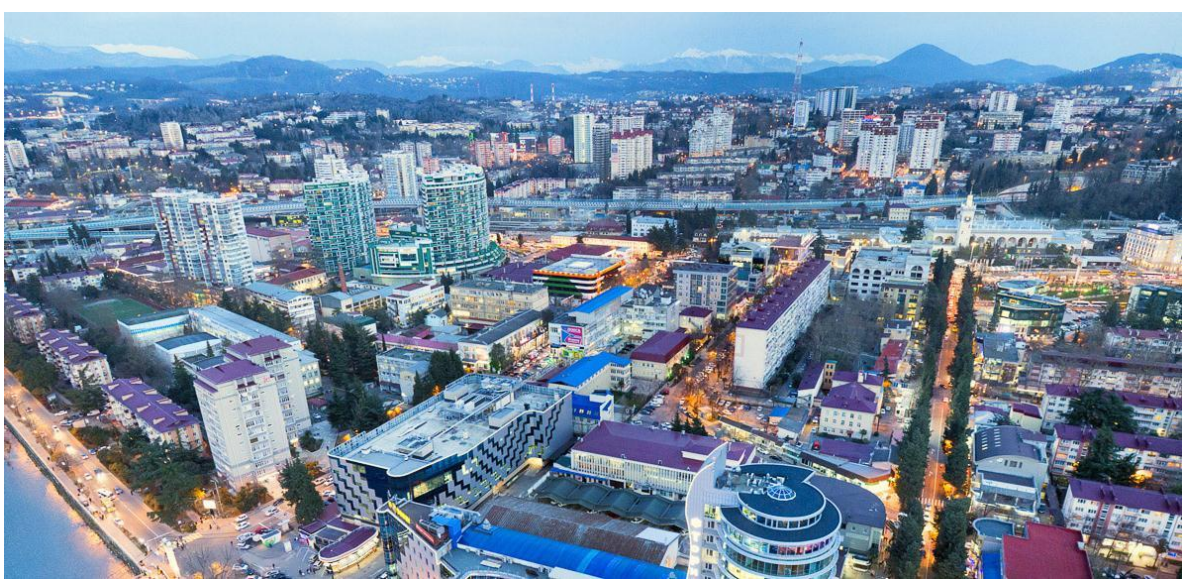

Fig. 1. Typical buildings in the central part of Sochi, erected in the 1960-90s along with modern development.

In accordance with current standards, the seismic intensity degree of the site construction by seismic zoning maps for the objects of this research is VIII by the MSK-64 scale. The selected representative houses did not exposed to landslide pressure and did not have an accident rate for this reason. The structures and floor plan solutions of the selected houses corresponded to the standards valid for the period of construction and background seismicity, which was absent for the territory of Sochi in the 1960s, in the 1970s it was the seismic intensity degree VII by the MSK-64 scale, and in the 1980-90s - the intensity VIII. The foundation for the surveyed buildings located in the flat areas of the city are prefabricated concrete strip foundation under bearing and self-supporting walls, if clay or loam, and for the buildings on slopes - reinforced concrete strip grilles on bored piles-pillars clamped into rock.

Thus, the estimated operational availability for representative buildings depends only on the quality of the materials used for construction, the timeliness of repair works, operational loads and damage from seismic influences over the period of operation, up to magnitude of 4 on the Richter scale. 


\section{Materials and Methods}

The initial information on the objects was obtained on the basis of the data of the conducted visual technical surveys in accordance with paragraph 4.4 of [3]. On the basis of [3], qualitative categories of the technical state of objects as a whole are established.

The following terms and definitions are used in accordance with section 3 [3]:

- normative condition: The category of technical condition in which the quantitative and qualitative values of the parameters of all criteria for assessing the technical condition of building structures and constructions, including the condition of the foundation soils, correspond to the values specified in the design documentation, taking into account the limits of their change.

- operational condition: The category of technical condition in which some of the estimated monitored parameters do not meet the requirements of the project or standards, but the existing violations of the requirements in the specific operating conditions do not lead to a malfunction, and the necessary load-bearing capacity of the foundation structures and grounds, defects and damages is ensured.

- limited operational condition: The category of technical condition of the building structure or buildings and structures in general, including the condition of the foundation soils, in which there are heels, defects and damages that lead to a reduction in the bearing capacity, but there is no danger of sudden destruction, loss of stability or overturning, and the functioning of structures and operation of a building or structure are possible either when control (monitoring) the technical condition, or when carrying out the necessary measures on restoration or reinforcement of structures and (or) foundation grounds and subsequent monitoring of technical condition (if it is necessary).

- emergency condition: The category of technical condition of the building structure or buildings and structures in general, including the condition of the foundation soils, characterized by the damages and deformations indicating the depletion of the bearing capacity and the danger of collapse and (or) characterized by banks that can cause loss of stability of the facility. Operation of buildings (structures) in the emergency conditions of structures, including ground base, is not allowed. A mandatory monitoring regime is established.

According to the technique [4], the conditional reliability estimate $\beta=1$ is good, 0.8 satisfactory, 0.6 - unsatisfactory, 0.4 - impermissible.

\section{Results}

According to the results of the survey:

a) the buildings of the 1960 s, represented by:

- five-storey frame-panel houses of the series 1-335 without anti-seismic measures as vertical structures that perceive the seismic load have reinforced-concrete columns along the internal longitudinal axis of $20 \times 20 \mathrm{~cm}$ section of concrete of class B 20, internal wall panels of staircases with a thickness of $14 \mathrm{~cm}$ of concrete of class B 15 , smoke ventilation panels with round holes of $28 \mathrm{~cm}$ in thickness from concrete of class B 20; as horizontal structures distributing the seismic load have $11 \mathrm{~cm}$ overlapping panels of room of concrete of class $\mathrm{B}$ 20-25; crossbars along transverse axes with a cross section of $20 \times 35 \mathrm{~cm}$ from concrete of class B 20. External wall panels are single-layer $27 \mathrm{~cm}$ thick claydite-clay concrete of class B 10. Defects in the form of cracks are found in the welds of panels of staircases, in seams and along the field of external wall panels. The conditional reliability $\beta=0,8$ is satisfactory. Forecasting endurance - the building is able to provide a standard operating life when performing local seismic reinforcement. Elimination of operational defects is possible after performing routine maintenance. 
- four-storey buildings without anti-seismic measures as vertical structures that perceive the seismic load have external and internal longitudinal bearing brick walls not strengthened with reinforcement in the seams, brick of the brand not higher than M75 in a complex solution of the brand not higher than M 75; as horizontal structures distributing seismic load: reinforced concrete floor panels with a width of 1.2 or $1.5 \mathrm{~m}$, a thickness of $22 \mathrm{~cm}$ with longitudinal circular voids, a class of concrete B 20. Defects in the form of cracks are found in the solution filling the seams between the slabs, especially in the outer compartments of the houses. The conditional reliability $\beta=0,8$ is satisfactory. Forecasting endurance - the building is able to provide a standard operating life when performing local seismic reinforcement. Elimination of operational defects is possible after performing routine maintenance.

- three-storey buildings, which were made of large blocks without anti-seismic measures as vertical structures that perceive the seismic load have concrete external and internal longitudinal bearing walls not reinforced and not connected by mortgage parts in seams, from concrete of class not higher than B 5 on cement-sand mortar of not higher than M 75; as horizontal structures distributing the seismic load they have reinforced concrete floor panels $1 \mathrm{~m}$ wide, $22 \mathrm{~cm}$ thick with longitudinal oval voids, concrete class B 15 . Defects in the form of cracks are found in the joints of the floor panels, especially in the outer compartments, as well as in the concrete blocks of class B 2.5 (fig. 2). The conditional reliability $\beta=0,8$ is satisfactory. Forecasting endurance - the building is able to provide a standard operating life when performing local seismic reinforcement. Elimination of operational defects is possible after performing routine maintenance.

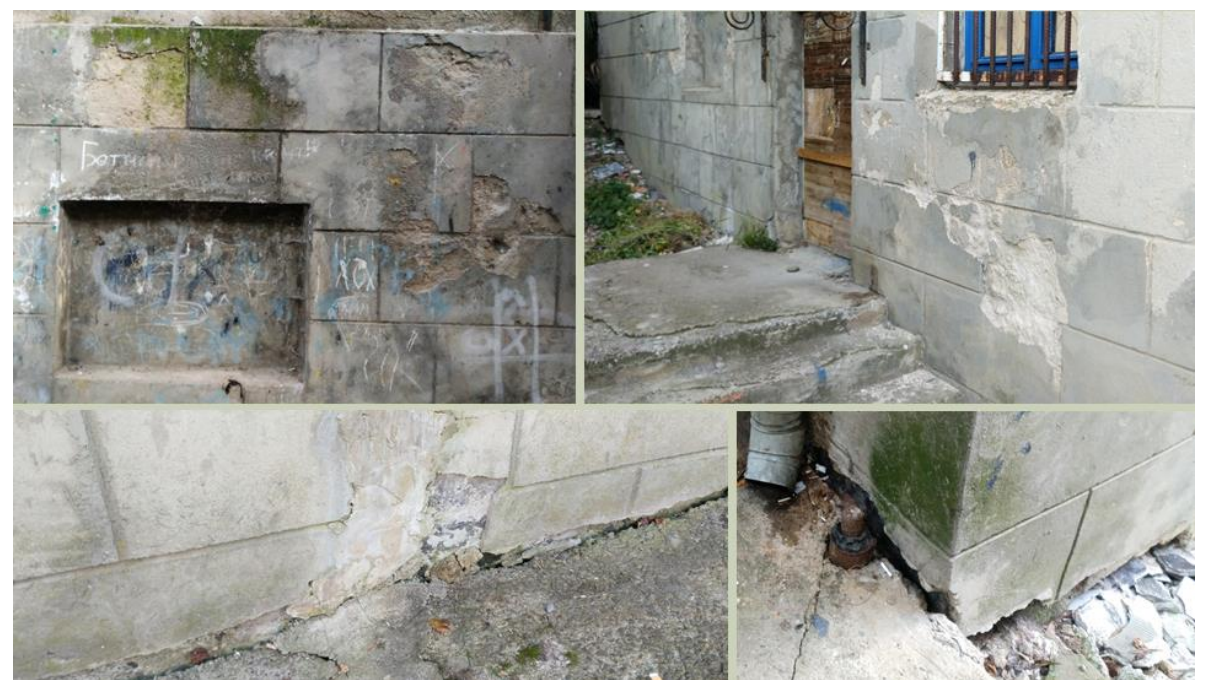

Fig. 2. Typical defects in three- and four-storey buildings made of large blocks in the 1960s.

b) the buildings of the 1970 s represented:

- five-storey frame-panel buildings of series 1-335 s with anti-seismic measures for the seismic intensity degree VII by the MSK-64 scale as vertical structures that perceive the seismic load have reinforced concrete columns along the internal and external longitudinal axes of $20 \times 40 \mathrm{~cm}$ section from concrete of class B 20, internal wall panels of staircases with a thickness of $16 \mathrm{~cm}$ from concrete of class B 15, smoke ventilation panels with round holes of $28 \mathrm{~cm}$ thickness from concrete of class B 20, reinforced concrete diaphragms along an internal longitudinal axis $8 \mathrm{~cm}$ thick of concrete of class no higher than B 10; since the horizontal elements of the overlap that distribute the seismic load have a thickness of $11 \mathrm{~cm}$ are made of concrete of class B 20 - B 25; crossbars along transverse axes with a cross section 
of $20 \times 35 \mathrm{~cm}$ from concrete B 20. External wall panels are single-layer $27 \mathrm{~cm}$ thick clayditeclay concrete of class B 10. Defects in the form of cracks are found in the welds of panels of staircases, in seams and along the field of external wall panels, in reinforced concrete diaphragms along the inner longitudinal axis in class B 5 concrete, in seams and along the field of external wall panels. The conditional reliability $\beta=0.9$ is satisfactory. Forecasting endurance - the building is able to provide a standard operating life when performing local seismic reinforcement. Elimination of operational defects is possible after performing routine maintenance.

- five-storey volumetric block buildings with anti-seismic measures for the seismic intensity degree VII by the MSK-64 scale (fig. 3)

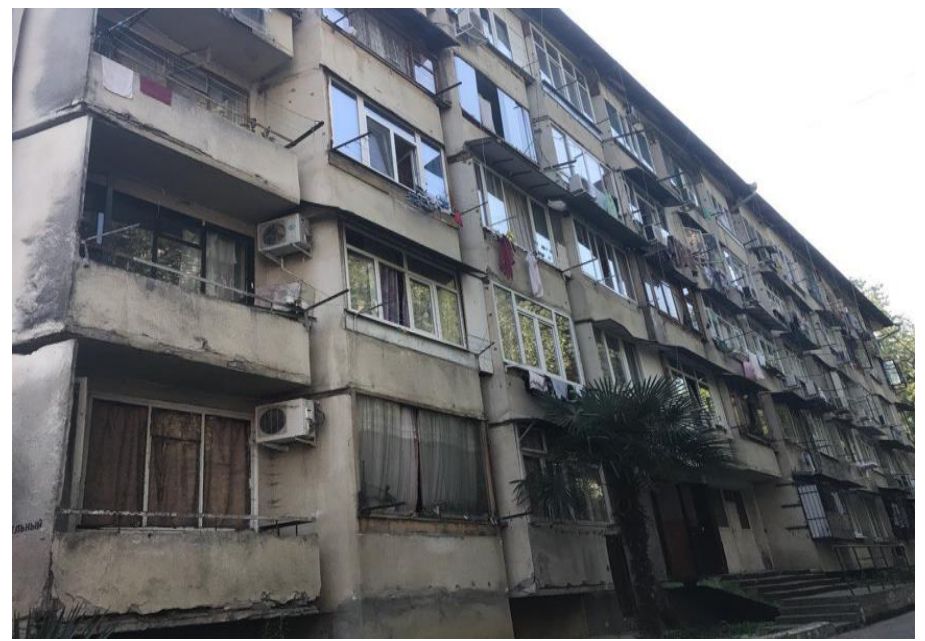

Fig. 3. Five-storey volumetric block building erected in the 1970's.

They were made of the prefabricated elements (room with walls except external), floor and ceiling of an element made of fine-grained ceramsite-reinforced concrete of class B 20; as horizontal structures of corridor overlays are reinforced concrete plates $11 \mathrm{~cm}$ thick of concrete class B 15, leaning on the internal walls of the volume-block elements. Enclosing structures are external single-layer wall panels $27 \mathrm{~cm}$ thick made of claydite concrete of class B 10. All elements are connected by a "hidden" monolithic reinforced concrete frame with a section of $10 \times 15 \mathrm{~cm}$. Defects in the form of cracks are found in the inner walls of corridors, external wall panels in the form of a bar as a result of detaching the protective layer of concrete. The conditional reliability $\beta=1$ is good. Forecasting endurance - the building is able to provide a standard operating life. Elimination of operational defects is possible after performing routine maintenance.

c) buildings of the 1980-90s

- twelve-storey buildings in the series 1-467 with large panels with anti-seismic measures for the intensity degree VII by the MSK-64 scale as vertical structures that perceive the seismic load have claydite-reinforced concrete external walls of $35 \mathrm{~cm}$ thick concrete of class B 12.5, internal reinforced concrete walls of $16 \mathrm{~cm}$ in thickness from concrete class B 20; as horizontal structures distributing the seismic load have reinforced concrete floor panels with a width of 1.2 and $1.5 \mathrm{~m}$, a thickness of $22 \mathrm{~cm}$ with longitudinal circular voids, a class of concrete B 20. Defects such as cracks were found in the mortar joints of panels, overlap joints of exterior wall panels. The conditional reliability $\beta=1$ is good. Forecasting endurance - the building is able to provide a standard operating life. Elimination of operational defects is possible during routine repairs.

- nine-storey buildings in series 1-135 with large panels with anti-seismic measures for 
the intensity degree VIII by the MSK-64 scale as vertical structures that perceive the seismic load, has claydite-reinforced concrete external walls of $35 \mathrm{~cm}$ thick concrete of class B 12.5, internal reinforced concrete walls of $16 \mathrm{~cm}$ in thickness from concrete class In 20, as horizontal structures that distribute the seismic load: claydite-reinforced concrete floor panels with a room size of $16 \mathrm{~cm}$, concrete class B 15-20. Defects in the form of cracks are found in the joints of external wall panels. The conditional reliability $\beta=1$ is good. Forecasting endurance - the building is able to provide a standard operating life. Elimination of operational defects is possible after performing routine maintenance.

\section{Discussion}

Analysis of the 1960s and 1970s construction defects showed that frame-panel, brick, largeblock houses require local seismic reinforcement and maintenance. At the same time for buildings with a three-dimensional structure, only current repairs are required.

Analysis of defects in the construction of the 1980s and 1990s showed that large-panel buildings require only routine repairs.

Local seismic retrofitting for buildings of the 1960s and 1970s with bearing walls can be done by introducing additional individual diaphragms of rigidity from monolithic reinforced concrete of class B 25 in the areas of staircases, increasing the stiffness of the floors by reinforced shirts or metal ties. Necessity and methods of reinforcing the frame-panel buildings of the five-storey series 1-335 were considered in [5] while carrying out the certification of the typical Ulan-Ude building. It is suggested to increase the corrosion resistance of embedded parts in the joints of crossbars and columns of a frame, slabs of galvanizing. It is noted that these nodes have a greater degree of compliance. The reliability of these joints determines the stability of the building in the longitudinal direction. At the survey [5], the authors found cracks in the joints of the outer panels along the entire height, vertical cracks in the smoke ventilation panels and in the jumpers of the entrance reinforced concrete panels of staircases. Seismic protection of buildings using seismic insulating supports is one of the promising and important technologies for Sochi and other seismic regions. This technology effectively solves the problem of seismic destruction from the action of transverse forces. The seismic resistance of such buildings is confirmed on the basis of full-scale vibration tests conducted with the participation of our specialists from Sochi State University.

As shown in [6], the current repair of a typical 1960-90s building should be mainly focused on excluding air permeability of horizontal seams of external wall panels, temperature-shrinkage deformations, accumulation of service moisture in vertical seams of external wall panels not filled with a solution according to requirements of the series; corrosion damage of embedded parts and welds at a speed of 0.1-0.2 mm per year in the joints of wall panels; corrosion damage to the reinforcement of external wall panels at a rate of 0.1 $0.3 \mathrm{~mm}$ per year due to the low density of the protective layer of claydite concrete in conditions of its moistening up to $70-95 \%$; corrosion of concrete bearing end wall panels; corrosion of concrete over the field of panels due to leakage of engineering communications.

Thus, the goal of current repairs should be the elimination of moisture - the main negative factor that reduces the operational availability of buildings of these series in the subtropical climate of the city of Sochi. Therefore, the main measure in the current repair of the wall is the plastering of external walls, internal walls of staircases.

Our experiments conducted in the laboratory of building materials of the Ecology and Engineering Faculty of Sochi State University showed that the dry cement-sand plaster mixture of the company "Osnova" has, along with the necessary adhesion, high strength of class B 10 and higher. In combination with vertical reinforcement in the form of wire mesh, this plaster composition can serve as a material that increases the seismic resistance of 
existing brick, large-block and panel walls.

At the moment, it is appropriate to develop a comprehensive target program aimed to ensuring seismic protection of socially significant and residential objects. Such programs, along with low-emission and climate-resilient development strategies (green LECRDS) would be the key elements of regional strategy of low-carbon sustainable development in Krasnodar region [7-8]. In preparation for the 2018 FIFA World Cup and other significant events, it is important to ensure that a proper set of measures is implemented to prevent the destruction or damage to buildings and infrastructure in the event of a severe earthquake. Also, it is necessary to carry out further surveys of socially important objects, life support systems and residential buildings within the framework of R \& D related topics, developing proposals on the best ways to increase their seismic resistance using new methods of calculation and modeling [9]. It is also necessary in the new construction and in the preventive improvement of the structural response to seismic actions of historical buildings to provide a mass application of innovative technologies which increase the earthquake resistance of buildings [10-11].

\section{Conclusions}

The implementation of a comprehensive program to provide seismic protection of socially significant and residential facilities aimed at implementing the objectives of the federal target program "Improving the sustainability of residential buildings and the main objects of lifesupport systems in seismic regions of the Russian Federation for 2009-2018" will limit negative operational impacts, normative endurance of residential development.

Analysis of the operational suitability of typical Sochi buildings shows that the operation of these buildings is possible by installing local seismic reinforcement in some buildings and in most cases with maintenance.

We intend to continue our further research in the field of organizing and conducting an express surveys of representative buildings and non-typical buildings of recent years in order to identify the presence or absence of seismic resistance deficit; installing remote control systems for the monitoring of load-bearing structures in representative buildings having a seismic deficit, development of standard recommendations for increasing seismic resistance of buildings. Within the framework of the Sochi State University development program as a Krasnodar region Flagship University, a comprehensive survey of the seismic safety and energy efficiency of buildings and structures of the Sochi resort agglomeration till year 2020 was planned.

\section{References}

1. Federal target program "Improving the sustainability of residential buildings and the main objects of life-support systems in seismic regions of the RF for 2009-2018" (2014) http://fcp.economy.gov.ru/cgi-bin/cis/fcp.cgi/Fcp/ViewFcp/View/ 2010/257/

2. E.N. Peresypkin, E.E. Yurchenko, Federal'naya tselevaya programma «Seysmobezopasnost' territorii Rossii (2002-2010 gg.)» primenitel'no k usloviyam Sochi, Stroitel'stvo v pribrezhnykh kurortnykh regionakh, Materialy 4-y nauchnoprakticheskoy konferentsii, Sochi, SGUTiKD, 4-13 (2006)

3. Russian Standard GOST 31937-2011

4. A.N. Dobromyslov, Otsenka nadezhnosti zdaniy i sooruzheniy po vneshnim priznakam, Izdatel'stvo ASV, 72 (2004) 
5. V.G. Barannikov, G.I. Tat'kov, A.D. Bazarov, M.P. Kalashnikov, Vestnik VostochnoSibirskogo gosudarstvennogo tekhnologicheskogo universiteta 1(36), 189-192 (2012)

6. E.N. Peresypkin, E.E. Yurchenko, E.A. Yurchenko, M.V. Moiseenko, Proc. Conf. (Izdvo Mosk. Gos. stroit. un-ta, 2017) http://mgsu.ru/resources/izdatelskayadeyatelnost/izdaniya/izdaniya-otkr-dostupa

7. A.N. Volkov, European researcher 10-2, 1761-1766 (2012)

8. N. Achour, E. Pantzartzis, F. Pascale, A. Price, International Journal of Disaster Resilience in the Built Environment, 6(3), 347-362 (2015) doi:10.1108/IJDRBE-052013-0016

9. E.N. Peresypkin, A.N. Volkov, S.J. Semyonov, Ecological Bulletin of Research Centers of the Black Sea Economic Cooperation 2-1, 30 (2016)

10. D. Shanmuga Priya, A. Cinitha, P.K. Umesha, N.R. Iyer, Journal of Structural Engineering (India) 42(3), 218-228 (2015)

11. C. Modena, F. Da Porto, M.R. Valluzzi, F. Carapezza Guttuso, P. Iannelli, C. Rubino, SAHC 2016, 35-43 (2016) 